Збірник наукових прачь Державного науково-дослідного інституту випробувань і сертифікачії озброєння та військової техніки. 2019. Вип. № 2

ISSN 2706-7386

Дмитрієв В.А., Шапоренко В.Г. Державний науково-дослідний інститут випробувань $i$ сертифікачії озброєння та військової техніки

\title{
АНАЛІЗ ВПЛИВУ КІЛЬКІСНИХ ПОКАЗНИКІВ РІВНЯ УНІФІКАЦІЇ ЗРАЗКІВ ОЗБРОСННЯ ТА ВІЙСЬКОВОЇ ТЕХНІКИ НА ЇХ ТЕХНІКО-ЕКОНОМІЧНУ ОЦНКУ
}

\begin{abstract}
Проведений аналіз впливу кількісних показників рівня уніфікації зразків озброєння та військової техніки на їх техніко-економічну оцінку та сформований методичний підхід до обтрунтування вимог до значень кількісних показників рівня уніфікації
\end{abstract} уніфікація.

Ключові слова: техніко-економічна оцінка, коефіцієнт застосовності, коефіцієнт повторюваності,

Кількісні показники рівня уніфікації для зразків озброєння та військової техніки (ОВТ) повинні входити до тактико-технічних завдань (ТТЗ) на виконання дослідноконструкторських робіт (ДКР) щодо їх створення (модернізацію) [1] з метою забезпечення високої якості зразків, зменшення термінів та витрат на їх проектування і підготовку виробництва, а також зменшення витрат на експлуатацію (ремонт) зразків. Високі показники рівня уніфікації визначають високу оцінку стандартизації зразка та, як наслідок, його техніко-економічну оцінку [2], [3]. Значення показників встановлюються на підставі аналізу показників прототипу або, при його відсутності, прогнозу можливих конструктивних рішень майбутнього зразка та порівняння з аналогами [4]. При цьому значення показників повинні бути не менше, мінімально встановлених органом виконавчої влади, провідним у розробці та виробництві зразків ОВТ даного виду [1].

Досягнуті кількісні показники рівня уніфікації оцінюються за етапами виконання ДКР та під час проведення приймальних (державних, міжвідомчих та інших) випробувань.

Оцінювання досягнутого рівня уніфікації виконується за коефіцієнтами застосовності $\left(K_{3}\right)$ та повторюваності $\left(K_{\Pi}\right)$ типорозмірів складальних одиниць та деталей зразка. Розрахунки коефіцієнтів $K_{3}$ та $K_{\Pi}$ виконуються за формулами [5,6]:

$$
K_{3}=\left(1-\frac{N_{o}}{N_{T}}\right) 100 \%, \quad K_{\Pi}=\frac{N_{\Sigma}}{N_{T}},
$$

де

$N_{T}$ - загальна кількість типорозмірів;

$N_{O}$ - кількість оригінальних типорозмірів;

$N_{\Sigma}$ - загальна кількість складових частин (складальних одиниць або деталей).

При цьому у розрахунках не враховуються кріпильні вироби (вінти, гайки, шплінти, шайби тощо), деталі тари та упаковки, слюсарно-збиральний інструмент та приладдя.

В останні роки в Україні проводиться декілька десятків ДКР зі створення нових та модернізації існуючих зразків ОВТ, при цьому:

скасовано декілька тисяч стандартів часів СРСР без розробки державних стандартів України на їх заміну;

застосування стандартів з обов'язкового у часи СРСР стало в Україні добровільним;

ДКР та роботи 3 імпортозаміщення проводять не тільки державні підприємства i організації, а й підприємства і організації національної економіки інших форм власності. Часто ці роботи виконуються за власні обігові кошти підприємств і організацій;

широко впроваджуються інноваційні технології;

відсутні встановлені вимоги щодо мінімальних показників рівня уніфікації для видів ОВТ та методичні рекомендації щодо обгрунтування відповідних вимог у ТТЗ.

Такий стан справ призвів до того, що у більшості випадків вимоги щодо рівня уніфікації у ТТЗ та технічних умовах не наводяться взагалі або наводяться без достатнього 
обгрунтування. Як наслідок, під час проведення випробувань можливо лише констатувати досягнутий рівень уніфікації без його оцінювання, що може негативно впливати на якість OBT, терміни та вартість іiі розробки та виробництва. Таким чином, дослідження 3 обгрунтування вимог до рівня уніфікації зразків ОВТ є актуальним.

Метою статті є формування методичного підходу до обгрунтування вимог до рівня уніфікації зразків ОВТ під час розробки ТТЗ на ДКР щодо їх створення та модернізації.

Аналіз формул (1) показує, що кількісні значення коефіцієнтів застосовності та повторюваності приймають наступні значення:

\section{a) $K_{3} \in[0,100 \%]$;}

$K_{3}=0-$ при $N_{O}=N_{T}$, тобто, коли усі типорозміри оригінальні;

$K_{3}=100 \% \quad-$ при $N_{O}=0$, тобто, коли оригінальні типорозміри відсутні;

б) $K_{\Pi} \in\left[1 ; N_{\Sigma}\right]$;

$K_{\Pi}=1-$ при $N_{T}=N_{\Sigma}$, тобто, коли усі складальні одиниці (деталі) мають різні типорозміри; $K_{\Pi}=N_{\Sigma}-$ при $N_{T}=1$, тобто, коли усі складальні одиниці (деталі) мають один типорозмір.

Загальний графічний вигляд залежності $K_{3}$ від $N_{O}$ (при вираженні $N_{O}$ у частинах $N_{T}$ ) та $K_{\Pi}$ від $N_{T}$ (при вираженні $N_{T}$ у частинах $N_{\Sigma}$ ) зображений на рис. $1,2$.

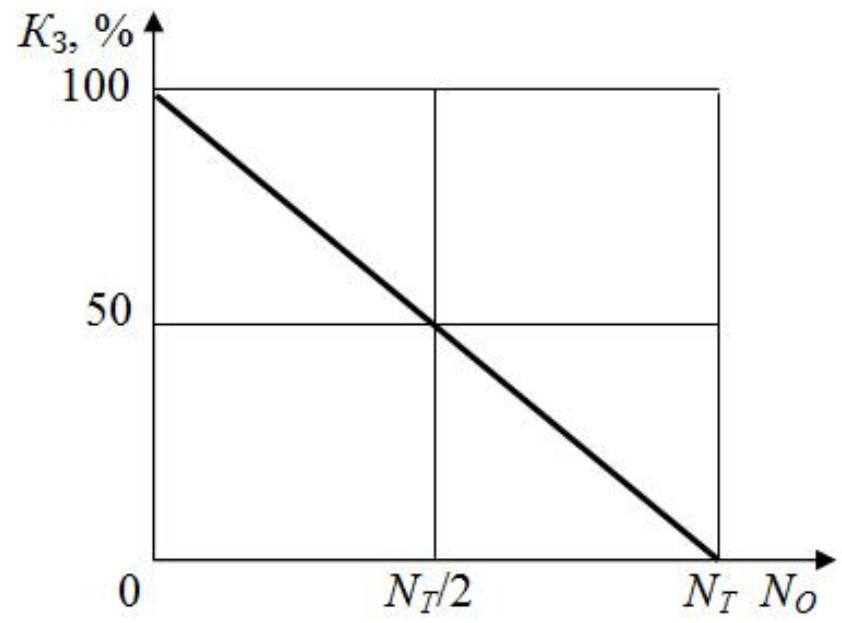

Рис. 1. Залежність $K_{3}$ від $N_{0}$

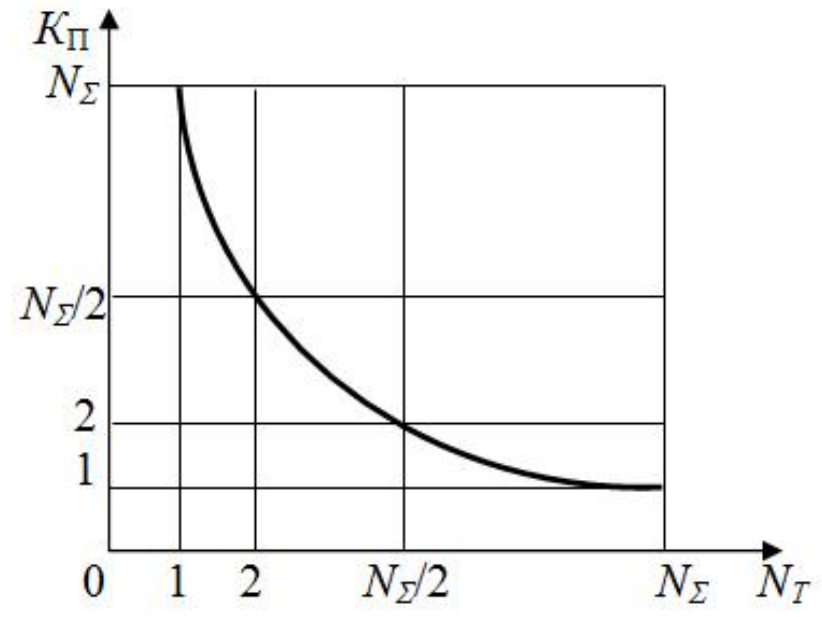

Рис. 2. Залежність $K_{\Pi}$ від $N_{T}$

У свою чергу функція $K_{\Pi}=f\left(N_{T}\right)$ надає значення коефіцієнту $K_{\Pi}$ у абсолютних непропорційних величинах, які незручно оцінювати (при пропорційних змінах $N_{T}$ зміни $K_{\Pi}$ непропорційні, особливо при невеликих значеннях $N_{T}$ ). Крім цього, максимальне значення коефіцієнту $K_{\Pi}$ дорівнює $N_{\Sigma}$, тобто встановити його нормативне значення на етапах проектування майже неможливо (кінцева кількість деталей зразка невідома). Порівнювати рівні уніфікації різних зразків також незручно та може сприяти хибній оцінці через те, що зразок з меншою кількістю деталей може мати максимальне власне значення коефіцієнту $K_{\Pi}$, яке менше $K_{\Pi}$ зразка з більшою кількістю деталей (наприклад, при $N_{\Sigma}=10$ од. і $N_{T}=1, K_{\Pi}=$ 10 (максимальне значення) та при $N_{\Sigma}=100$ од. і $N_{T}=5, K_{\Pi}=20$ (при максимальному значенні $-100)$.

Вказаних недоліків можна позбавитися заміною коефіцієнту $K_{\Pi}$ на відносний коефіцієнт $K_{\Pi \text {, }}^{*}$ який розраховується за формулою:

$$
K_{\Pi}^{*}=\left(1-\frac{N_{T}-1}{N_{\Sigma}}\right) 100 \% .
$$

Загальний вигляд залежності $K_{\Pi}^{*}$ від $N_{T}$ наведений на (рис. 3$)$. 


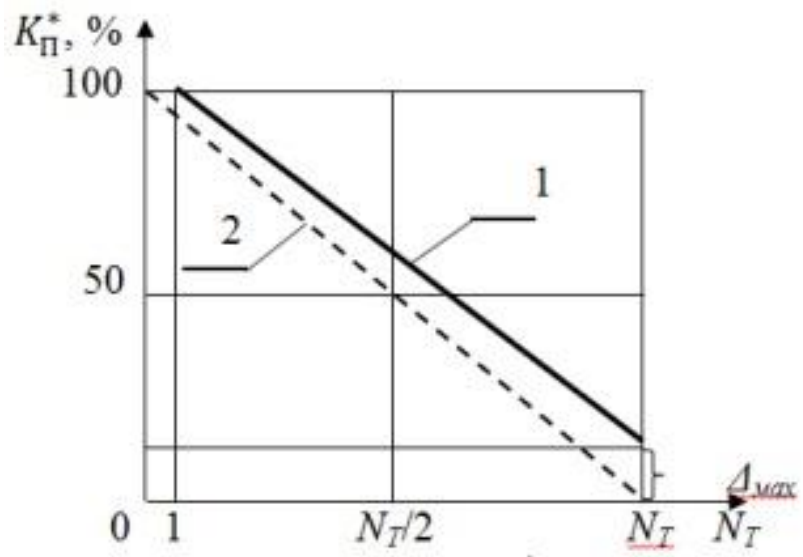

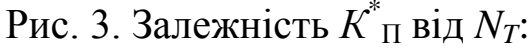

1 - згідно формули (2); 2 - бажана.

Відміна графіку функції $K_{\Pi}^{*}=f\left(N_{T}\right)$ (лінія 1 на рис. 3) від бажаної лінії (штрихова лінія 2 на рис. 3) обумовлена тим, що кількість типорозмірів визначається цілими числами починаючи 3 одиниці. При цьому максимальна різниця $\left(\Delta_{\text {мах }}\right)$ між значеннями $K_{\Pi}^{*}$ за формулою (2) та бажаним значенням відповідає невеликим значенням рівня уніфікації (див. рис. 3), які не можуть бути прийняті у якості вимог до ОВТ. Окрім цього, значення $\Delta_{\text {мах }}$ при зростання кількості деталей $\left(N_{\Sigma}\right)$, зменшується та, наприклад, при $N_{\Sigma}=100$ одиниць $\Delta_{\max }$ складає $1 \%$, що цілком прийнятно.

Таким чином, запропонований коефіцієнт $K_{\text {п }}^{*}$ доцільно використовувати замість коефіцієнту $K_{\Pi}$ під час встановлення вимог та визначення досягнутого рівня уніфікації зразків ОВТ.

Для проведення подальших досліджень умовно приймемо такі показники:

досконалість (Д) - рівень якості зразка ОВТ при певному рівні його уніфікації;

вартість $(B)$ - вартість проектування та підготовки виробництва зразка ОВТ при певному рівні його уніфікації;

термін $(T)$ - строк проектування та підготовки виробництва зразка ОВТ при певному рівні його уніфікації.

3 логічних заключень приймемо, що при зростанні коефіцієнтів $K_{3}$ та $K^{*}$ п показник Д зростає, а показники $B$ та $T$ зменшуються. Для попереднього аналізу приймемо також, що

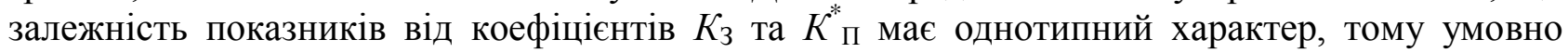
можливо розглядати один коефіцієнт $-K$.

У прийнятих припущеннях загальний вид залежності показників Д, $B$ та $T$ від $K$ наведений на рис. 4.

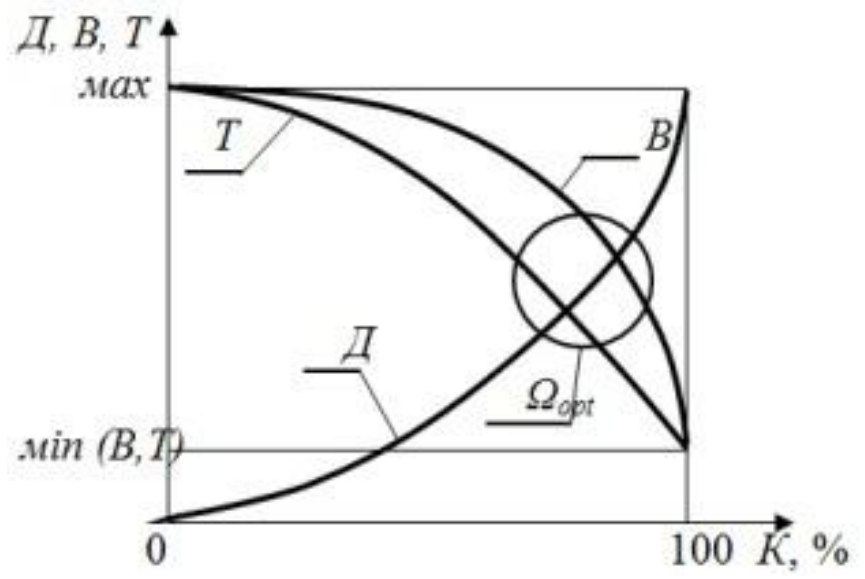

Рис. 4. Залежність Д, $B, T$ від $K$ 
Аналіз графіків показує, що:

при нульовому рівні уніфікації $(K=0)$ досконалість зразка рівна нулю, а вартість і терміни проектування та підготовки виробництва мають максимальні значення, тобто техніко-економічна оцінка зразка низька, й встановлення такого рівня уніфікації недоцільно;

при максимальному рівні уніфікації $(K=100 \%)$ зразок максимально досконалий, а витрати і терміни проектування та підготовки виробництва - мінімальні, тобто технікоекономічна оцінка зразка висока, й такий рівень уніфікації є бажаним.

Однак, практика проведення ДКР та випробувань показує, що при проектуванні зразків ОВТ неможливо досягнути максимального рівня уніфікації через багаточисельність складових частин і деталей, різноманіття їх призначення тощо. Крім цього, високий рівень уніфікації може призвести до суперечливості 3 іншими вимогами до ОВТ, таких як ефективність застосування за призначенням, мінімальні масо-габаритні характеристики, висока ергономічність тощо. Характерний приклад - вимоги до довжини злітно-посадкової смуги для літака змусили проектантів зменшити його масу, внаслідок чого рівень уніфікації знизився з $80 \%$ до $35 \%$, тобто у 2,25 рази [7].

Також, має місце питання можливості досягнення і доцільності встановлення високого рівня уніфікації під час інноваційних розробок, глибокої модернізації, створення унікальних (одиночних, малосерійних) зразків ОВТ.

Таким чином, постає задача визначення оптимального рівня уніфікації, очікувана область якого $\left(\Omega_{\text {opt }}\right)$ наведена на (рис. 4$)$.

Вирішення такої задачі дуже складне i можливе лише на рівні прогнозів із застосуванням статистичних даних (за аналогами, вартістю і тривалістю проектування та підготовки виробництва), база яких відсутня та як правило відомості $\epsilon$ комерційною таємницею.

За таких обставин прийнятним рішенням може бути розрахунок рівня уніфікації за формулою:

$$
K=K_{\text {баз }} \times \frac{\sum_{i=1}^{n} C_{i}}{n},
$$

де $\quad K_{\text {баз }}-$ базовий рівень уніфікації (базове значення коефіцієнту $K_{3}$ або $K_{\Pi}$ );

$n$ - кількість факторів, які впливають на рівень уніфікації;

$C_{i}-$ коефіцієнти факторів, які впливають на рівень уніфікації.

До факторів, які впливають на рівень уніфікації, можна віднести новизну розробки, складність зразка, серійність, досвід розробника тощо.

Таким чином, може бути запропонований такий загальний методичний підхід до обгрунтування кількісних показників рівня уніфікації:

1) визначення базового рівня кількісних показників рівня уніфікації;

2) визначення переліку факторів, які впливають на рівень уніфікації;

3) визначення коефіцієнтів факторів, які впливають на рівень уніфікації;

4) розрахунок кількісних показників рівня уніфікації за формулою (3).

Проблемним питанням такого методичного підходу є відсутність єдиного принципу та рекомендацій виконання пунктів 1-3 наведеного методичного підходу, що потребує подальших досліджень.

Висновки. За результатами проведених досліджень:

обгрунтована пропозиція щодо доцільності заміни коефіцієнту повторюваності на відносний коефіцієнт повторюваності для встановлення і оцінки рівня уніфікації зразків OBT;

сформований методичний підхід до обгрунтування вимог до кількісних показників рівня уніфікації зразків ОВТ. 


\section{СПИСОК ЛІТЕРАТУРИ}

1. Порядок задания требований по унификации и стандартизации в техническом задании: ГОСТ 23945.2-80 . - М.: Издательство стандартов, 1982. - 6 с. - (Государственный стандарт Союза ССР).

2. Загальні поняття про стандартизацію. - К.: Управління стандартизації, кодифікації та каталогізації Міністерства оборони України, 2016. - 85 с.

3. Дмитрієв В.А. Пропозиції щодо оцінки відповідності (сертифікації) матеріалів та виробів, які застосовуються у зразках озброєння, військової та спеціальної техніки: тези доповіді. / В.А. Дмитрієв, А.Г. Козир, В.Г. Шапоренко. // Збірник матеріалів XIX науковотехнічної конференції “Створення та модернізація озброєння і військової техніки в сучасних умовах”. - Чернігів: ДНДІ ВС ОВТ, 2019. - С. 87-88.

4. Уніфікація продукції. [Електронний ресурс]. - Режим доступу: https://studme.com.ua/19421117/tovarovedenie/unifikatsiya_produktsii.htm.

5. Показники рівня уніфікації. [Електронний ресурс]. - Режим доступу: https://studme.com.ua/17220206/tovarovedenie/pokazateli_urovnya_unifikatsii.htm\#554.

6. Принцип унификации конструкций изделий. [Електронний ресурс]. - Режим доступу: http://de.ifmo.ru/bk_netra/page.php?index=30\&layer=1\&tutindex=37.

7. Боас, Райан. Унификация: и хочется, и колется. [Електронний ресурс]. / Райан Боас, Эдвард Кроли. - 2011. - Режим доступу: https://hbr-russia.ru/management/operatsionnoeupravlenie/a11094.

\section{Дмитрієв Володимир Анатолійович}

лауреат Державної премії України в галузі науки і техніки, доктор філософії, старший науковий співробітник, заступник начальника інституту 3 наукової роботи, Державного науково-дослідного інституту випробувань і сертифікації озброєння та військової техніки, Чернігів, Україна https://orcid.org/0000-0002-0792-6397 $+38-095-462-56-37$

\section{Шапоренко Вікторія Григорівна}

науковий співробітник Державного науководослідного інституту випробувань i сертифікації озброєння та військової техніки, Чернігів, Україна https://orcid.org/0000-0002-0649-3112 +380669137373

\section{Volodymyr Dmytriiev}

The Laureate of State Prize of Ukraine in sphere of science and technique, Doctor of Philosophy, Senior Researcher, Deputy Chief of State Scientific Research Institute of Armament and Military Equipment Testing and Certification (on Research), Chernihiv, Ukraine https://orcid.org/0000-0002-0792-6397 $+38-095-462-56-37$

\section{Viktoriia Shaporenko}

Researcher of State Scientific Research Institute of Armament and Military Equipment Testing and Certification, Chernihiv, Ukraine https://orcid.org/0000-0002-0649-3112 +380669137373 


\section{ANALYSIS OF THE INFLUENCE OF QUANTITATIVE INDICATORS OF THE LEVEL OF UNIFICATION OF WEAPONS SAMPLES AND MILITARY EQUIPMENT ON THEIR TECHNICAL AND ECONOMIC EVALUATION

\author{
V. Dmytriiev, V. Shaporenko
}

The article analyzes the influence of quantitative indicators of the level of unification of armament and military equipment (AME) on their technical and economic assessment and formed a methodical approach to justify the requirements for the values of quantitative indicators of the level of unification of samples of AME.

Quantitative indicators of the unification level of samples of AME should be included in their terms of reference to execute the research and development work of their creation (modernization) in order to ensure high quality of samples at the design stage, reducing the time and cost of their design and preparation of production, as well as reducing the cost of operation (repair) of samples. The assessment of the achieved level of unification is performed by the coefficients of applicability and repeatability of the standard sizes of the assembly units and details of the sample. In the recent years in Ukraine, in the most cases, the requirements for the level of unification in the terms of reference are not stated at all or are not sufficiently substantiated. As a result, during testing there is only possibility to ascertain the achieved level of unification without evaluating it, which may have the adversely affect on the quality and technical and economic performance of AME.

The values of the coefficient of applicability are obtained in relative proportional values. That allows to establish convenient conditions for evaluateion the level of unification of the sample itself on the stages of creation, and compare the levels of unification of different samples with each other. The values of the coefficient of repeatability are obtained in values that are inconvenient to estimate and compare. To eliminate the inconvenience, the article proposes to use a relative coefficient of repeatability.

The analysis of the influence of the coefficient of applicability and the relative coefficient of repeatability on the indicators of perfection, cost and term of design and preparation of production of the sample of AME showed that there is an optimal level of unification, the values of which belong to the field Sopt. The article proposes a methodical approach to the determination of such values by the basic level of unification, taking into account the coefficients of factors that influence the level of unification (novelty of development, complexity of the sample, seriality, experience of the developer, etc). unification.

Keywords: technical and economic evaluation, coefficient of applicability, coefficient of repeatability, 